\title{
Microvascular and macrovascular endothelial function in two different types of primary aldosteronism
}

\author{
Toru Kato ${ }^{1} \cdot$ Koichi Node ${ }^{2}$
}

Received: 25 September 2018 / Revised: 15 October 2018 / Accepted: 15 October 2018 / Published online: 6 December 2018

(C) The Japanese Society of Hypertension 2018

Primary aldosteronism (PA) is a type of secondary hypertension that is caused by aldosterone overproduction and oversecretion from the adrenal glands. Aldosterone-producing adenoma (APA) of the unilateral adrenal cortex accounts for $80-90 \%$ of PA cases; the remaining $10-20 \%$ are bilateral idiopathic hyperaldosteronism (IHA).

PA is more likely to be complicated by myocardial infarction and stroke compared with essential hypertension (EHT). This finding may be due to worse endothelial function that is caused by higher circulating levels of aldosterone in PA compared with that in EHT.

A previous study showed that flow-mediated dilation (FMD) was significantly lower in patients with APA than in those with IHA and EHT [1]. In the present study, the authors demonstrated that microvascular, but not macrovascular, endothelial function was impaired in patients with IHA compared to those with EHT, although FMD was similar between IHA and EHT patients [2].

Microvascular endothelial function was evaluated using the log-transformed reactive hyperemic index (log RHI) as measured by RH-peripheral arterial tonometry (RH-PAT) [2]. FMD and log RHI reflect macrovascular and microvascular endothelial functions, respectively [3, 4].

Aldosterone increases inflammation and fibrosis in the vasculature, resulting in endothelial dysfunction [5-8]. Moderately elevated plasma aldosterone concentration (PAC) in IHA impairs microvascular endothelial function, whereas the greatly elevated PAC in APA impairs both microvascular and macrovascular endothelial functions.

Koichi Node

node@cc.saga-u.ac.jp

1 Department of Clinical Research, National Hospital Organization Tochigi Medical Center, Tochigi, Japan

2 Department of Cardiovascular Medicine, Saga University, Saga, Japan
Table 1 Comparison of the two types of primary aldosteronism : IHA and PA

\begin{tabular}{lll}
\hline & IHA compared with EHT & $\begin{array}{l}\text { APA compared with } \\
\text { EHT }\end{array}$ \\
\hline $\begin{array}{l}\text { Plasma PAC } \\
\text { level }\end{array}$ & Moderately increased & Greatly increased \\
$\begin{array}{l}\text { Log RHI and } \\
\text { FMD }\end{array}$ & Only log RHI decreased & $\begin{array}{l}\text { Both log RHI and } \\
\text { FMD decreased }\end{array}$ \\
$\begin{array}{l}\text { Impaired } \\
\text { vascular bed } \\
\text { size }\end{array}$ & Microvascular endothelium & $\begin{array}{l}\text { Micro- and macro- } \\
\text { vascular endothelium }\end{array}$ \\
$\begin{array}{l}\text { First-line } \\
\text { treatment }\end{array}$ & $\begin{array}{l}\text { Mineralocorticoid receptor } \\
\text { antagonists and renin- } \\
\text { angiotensin aldosterone }\end{array}$ & $\begin{array}{l}\text { Surgical resection of } \\
\text { the adrenal adenoma }\end{array}$ \\
& inhibitors & \\
\hline
\end{tabular}

$A P A$ aldosterone-producing adenoma, EHT essential hypertension, $F M D$ flow-mediated dilation, IHA idiopathic hyperaldosteronism, $P A C$ plasma aldosterone concentration, $R H I$ reactive hyperemic index

Surgical resection of APA improved FMD in patients with APA [1]. However, it remains unclear whether mineralocorticoid receptor antagonists, angiotensinconverting enzyme inhibitors, angiotensin receptor blockers, renin inhibitors, beta-blockers, and some calcium channel blockers can improve the log RHI in patients with IHA (Table 1). Further studies are needed to elucidate this issue.

\section{Compliance with ethical standards}

Conflict of interest The authors declare that they have no conflict of interest.

\section{References}

1. Matsumoto T, Oki K, Kajikawa M, Nakashima A, Maruhashi T, Iwamoto $\mathrm{Y}$, et al. Effect of aldosterone-producing adenoma on endothelial function and Rho-associated kinase activity in patients with primary aldosteronism. Hypertension. 2015;65:841-8. 
2. Kishimoto S, Matsumoto T, Oki K, Maruhashi T, Kajikawa M, Matsui S, et al. Microvascular endothelial function is impaired in patients with idiopathic hyperaldosteronism. Hypertens Res. 2018;41:932-8.

3. Hamburg NM, Palmisano J, Larson MG, Sullivan LM, Lehman BT, Vasan RS, et al. Relation of brachial and digital measures of vascular function in the community: the Framingham heart study. Hypertension. 2011;57:390-6.

4. Lee CR, Bass A, Ellis K, Tran B, Steele S, Caughey M, et al. Relation between digital peripheral arterial tonometry and brachial artery ultrasound measures of vascular function in patients with coronary artery disease and in healthy volunteers. Am J Cardiol. 2012;109:651-7.

5. Nakano S, Kobayashi N, Yoshida K, Ohno T, Matsuoka H. Cardioprotective mechanisms of spironolactone associated with the angiotensin-converting enzyme/epidermal growth factor receptor/ extracellular signal-regulated kinases, $\mathrm{NAD}(\mathrm{P}) \mathrm{H}$ oxidase/lectin-like oxidized low-density lipoprotein receptor-1, and Rho-kinase pathways in aldosterone/salt-induced hypertensive rats. Hypertens Res. 2005;28:925-36.

6. Griol-Charhbili V, Fassot C, Messaoudi S, Perret C, Agrapart V, Jaisser F. Epidermal growth factor receptor mediates the vascular dysfunction but not the remodeling induced by aldosterone/salt. Hypertension. 2011;57:238-44.

7. Nagata D, Takahashi M, Sawai K, Tagami T, Usui T, Shimatsu A, et al. Molecular mechanism of the inhibitory effect of aldosterone on endothelial NO synthase activity. Hypertension. 2006;48:165-71.

8. Keidar S, Kaplan M, Pavlotzky E, Coleman R, Hayek T, Hamoud $\mathrm{S}$, et al. Aldosterone administration to mice stimulates macrophage NADPH oxidase and increases atherosclerosis development: a possible role for angiotensin-converting enzyme and the receptors for angiotensin II and aldosterone. Circulation. 2004;109:2213-20. 